\section{Motion and Rest from a Chinese Buddhist Perspective}

ABSTRACT: This paper focuses on Seng-Chao's conception of motion and rest as two different ways to see the same phenomenon and the effect that this has on his understanding of ideas such as impermanence. I point out the parallels that can be made between motion and rest and samsara and nirvana and I argue that a strong Taoist background helps Seng-Chao clarify Indian ideas and make even deeper claims about the true nature of reality.

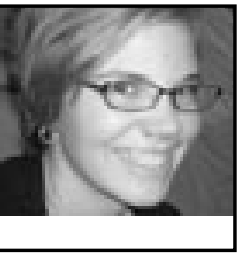

eng-Chao's writing as a Chinese Buddhist signified the start to a new 7 development in Buddhist philosophy in China. ${ }^{2}$ He was one of the Coctrine) School, which hadition called the Three-Treatise (or Middle igne significant texts, namely Naggarjuna 's ${ }^{2}$ Treatise on the Middle way, and Treatise

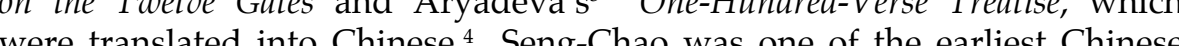
were translated into Chinese. Seng-Chao was one of the earliest Chinese philosophess inter Taoist and Confucian society. While his work is grounded in distinctly Buddhist ideas, there are definite Taoist influences to his perspective.

Smith Colle

Caroline Sluyter

is a senior at

Smith College

in Northampton,

MA. She

is a philosophy

major, a logic

Buddhist studies

certificate

student. She

is interested in

is interested in

and Chinese

philosophy and

is working on

an independent

project on the two

truths within the

Tibetan

philosophical drawing on connections this argument has with Nāgārjuna's account of motion and Śāntaraksita's ${ }^{5}$ account of consciousness and memory in relation to the perception of images. Next I will examine Seng-Chao's discussion of time and the relationship between past, present and future. I will make connections to Candrakītri's $\mathrm{s}^{6}$ account of memory and its implications on

1. Chinese religious and philosophical thought was almost entirely Confucian and Taoist until the transmis-
sion of Buddhism began via the Silk Road from India to China. Seng-Chao was one of the first Chinese scholars to engage seriously with the Buddhist philosophical texts being brought from India

2.Nāgărjuna was an extremely influential Indian philosopher whose writing marks the start of the Māadhyamika (Middle Way) School of Mahăyāna Buddhism. The most famous of his works, Mūlamadhyamakakārik

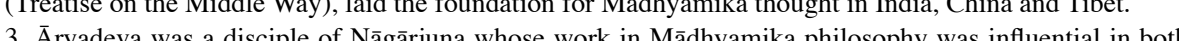
China and Tibet.

4. These three texts were purportedly authored by Nāgărjuna and Āryadeva and were transmitted to China by a monk named Kumārijiva, whose father has been Indian and mother had been Chinese. Kumärijiva and his disciples (including Seng-Chao) translated these texts creating what is referred to as the Three-Treatise School of Chinese Buddhism. 5. Sântaraksita was an Indian philosopher, labeled in Tibetan doxography as a Yogāaciara-śvātantrikaMadadhyamika. His account of conventional truth follows that of the Yogäcăra (Mind-Only) idealist schood nized by it in a non-dual reflexive manner. His method of logical argument and reasoning follows that of the Svātantrika style of autonomous inference. And his account of ultimate truth classifies him a Mādhyamika because he believes that ultimately, everything (including mind) is empty of inherent existence. 6. Candrakîrti was a disciple of Nãgărjuna and wrote commentaries on many of his texts. He follows the Prāsangika style of logic which means that he does not believe that statements or accounts of the ultimate

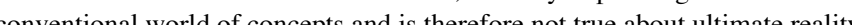

what constitutes the past versus the present. I will argue that an analogy can be made between Seng-Chao's observations about motion and rest and the relationship between samsāra ${ }^{7}$ and nirvāna ${ }^{8}$. Finally I will argue that even though Seng-Chao deviates from his Indian and Tibetan counterparts on a number of points, his philosophical perspective serves to augment and clarify the Buddhist tradition and shed new light on a number of important Buddhist doctrines.

Seng-Chao begins his treatise The Immutability of Things by explaining that he disagrees with the commonly accepted idea that time flows like a current along which all things move, changing with it. While Seng-Chao does not outline his specific objections to this analogy, there are many problems with it The image of a current or river of time suggests properties that cannot be possessed by time or motion. First of all, seeing time as a river would imply that past, present and future all exist somewhere at all times and to locate any moment (past present present, and future all exist somewhere at all times and to locate any moment (past, present or future) would require nothing more than figuring out where that moment was positioned in a long string of moments. It would imply that, in some way, it might be possible to locate and return to a past me river as an an time. On like. Finlly, if time is repested ine time is flowing whe experiencing the cis He begins with an examination of the relation He begin with an examination or the relationship between motion and rest. Instead of thinking of the look for rest in mont in mon, therefor ( cannot be other than multiple instances of rest. While he is not arguing that motion does not exist, he is making a claim about the role that rest plays within movement. He would like to say that there is perpetual rest and that motion mus grow out of 1 . At the same the, he is not arguing against the Buddhist idea that everything is constantly changing. Within rest, there is also constant motion. According to Seng-Chao, motion and rest are the same phenomenon seen from different perspectives.

These ideas are grounded in Nāgārjuna's discussion of motion in his Mūlamadhyamakakārikē (Treatise on the Middle Way). "What has been moved is not moving. What has not been moved is not moving. Apart from what has been moved and what has not been moved, movement cannot be conceived." ${ }^{10}$ Nāgārjuna identifies three pieces to the conventional

7. Samsära is the Sanskrit word for cyclic existence which is the cycle of death and rebirth in which all sentient beings are trapped because of their ignorance and grasping. This is a term which describes the very world we live in. The is also an account of the very world in which we live and does not describe some other realm of ex or at rest. It is important to note 9. Wing-Tsit Chan, A Source Book in Chinese Philosophy (Princeton: Princeton University Press, 1969): 345

10. Jay L. Garfield, The Fundamental Wisdom of the Middle Way (New York: Oxford University Press, 1995): 125. (Chatpter II, verse 


\section{Motion and Rest from a Chinese Buddhist Perspective}

understanding of motion: (1) the subject (the mover); (2) the action (the movement); and (3) the object (the moved). However, motion itself cannot be located in any of these three things. Moreover, there are three tenses in which motion is understood: (1) the past (what was moved); (2) the present (what is moving); and (3) the future (what has not yet been moved). What was moved is no longer moving so motion cannot be found in it. What has not yet been moved is not moving either, and therefore does not contain motion. Movement implies that something has changed. What has moved has started in one place and ended up in another Motion therefore can only be understood in relation to time. At any one moment nothing is moving because there is no conception of something having changed location or position. In a sense, it is frozen at that instant in place in whatever location it rests. For this reason. ing (1) mate up of rest.

Even as Seng-Chao explains motion as multiple instances of rest, he maintains that there is also motion within those very instances of rest. An instant, after all, is just a miniscule duration of $i$ we and all hings are in a enstant state of change. Even if there is no change that can be observed by human senses within that instant, everything in existence during the passing of that instant has aged by a tiny bit which is an indication of change. Since motion passing of that instant has aged by a thy bit which is an indication of change. Since motion

In his treatise Seng-Chao is making metaphysical claims about the way motion and

rest function rest function and work in tandem whe each other. Nagaryuna is also using metaphysical arguments in his discussion, though he is concerned with more than the way that motion works. Nagarjuna is deconstructing the words we use to talk about motion and is trying to it. In that we cannot locate our concept of that action within the words we use to describe it. In doing this, he is also arguing that all things are empty of inherent existence, and that motion itself is also empty. The biggest difference between Seng-Chao and Nāgārjuna is that Seng-Chao is not concerned with the same argument about the ultimate emptiness of everything. In the end, however, their metaphysical claims remain remarkably similar.

Seng-Chao's account of multiple instances of rest making up motion can be compared to Sāntaraksita's explanation of the way that images are perceived in his Madhyamakālamkār (Ornament of the Middle Way). Santaraksita believes that images are perceived in multiple, distinct pieces rather than as a fluid continuum. Every instant the object appears to the eye and the eye perceives the image of that object. The mind then stores that image in memory. It is memory and not the eye, Śantaraksita thinks, that blurs images together so that the observer gets the sense that she is perceiving a continual occurrence of an object, when in reality, she is only seeing a series of still images. The "joining of the boundaries is done by the memory [of the mental consciousness], not by the seeing [of an eye consciousness] because that [eye consciousness] cannot apprehend past objects."1

Sanntaraksita uses the example of a swinging firebrand to demonstrate his idea. When a person observes a firebrand being swung in a circle, the impression that the viewer gets is that of a continuous circle of fire. The observer knows that the firebrand is not actually becoming a circle, but instead that a spot of fire is being moved from location to location in a circular motion fast enough that it is being seen as such. Santaraksita would like to sugges that a person's eyes take in individual images of the spot of fire at distinct locations in its 11. James Blumenthal, The Ornament of the Middle Way: A Study of the Madhyamaka Thought of Śantaraksita (Ithaca: Snow Lion
Caroline Sluyter

circular path, and that the mind uses memory to blur the boundaries between those images, giving the viewer the impression of a continuous circle.

There are obviously many similarities between Śāntaraksita's account of memory and perception and Seng-Chao's ideas about motion. They are both suggesting that it is necessary to break down what seems like something continuous into instants of time in order to fully understand the nature of motion and memory. Sanntaraksita is providing an epistemological explanation for the way perceptions are acquired, which explains the relationship between mind and external objects and the differences between the two. Seng-Chao, however, is making a metaphysical claim about the nature of all of existence and the very way in which that existence exists. This claim is much deeper than that of Śantaraksita's because it is relevant to every part of life and is not confined to an account of how our mind interacts relevant to every part of life and is not confined to an account of how our mind interacts with the external world. It leads to conclusions about
clarify the relationship between past, present and future.

clarify the relationship between past, present and future. Following his discussion of motion and rest, for instance, Seng-Chao engages in an examination of time and common (mis)conceptions about the relationship between past, present and future. no notion of the past coming into the present or the present moving into the past.

If the present passes on to the past, then there should be the present in the past. If the past reaches to the present, then there should be the past in the present. Since there is no past in the present, we know it does not come, and since there is no pest, we know it does not go... every thing, according to its nature, remains for only one period of time. ${ }^{12}$

The past comprises everything that already occurred in the present and is no longer found there, and the future is made up of everything that has yet to occur in the present and so cannot yet be found there. Those who say the present moves into the past are wrong because there is no instance of the present in the past. The present has not gone anywhere. The present does not move into the past, just as the past cannot move into the present. Therefore, memories of past experiences are of things that remain in the pas

Candrakīrti makes similar conclusions in his discussion of memory in the Madhyamakāvatāra (Introduction to the Middle Way). It would be "illogical to assert that a memory constitutes remembrance [of an actual experience]. In fact, it would be entirely different from [that previous experience], just as much as if it had been produced in a continuum that did not include any cognition [of that earlier experience]."13 He is refuting the Yogācārin understanding of memory, which claims that memory is based on an awareness of oneself performing an action or going through an experience. On the Yogācārin account, it seems that memory is a kind of reliving of the past. A person recalls what it was like to be aware of going through an experience, and therefore is able to experience it all over again using memory. Candrakirti wants to emphasize the fact that the experience remains in the past and cannot be relived. Instead, a memory is a present impression of a past experience. He 12. Wing-Tsit Chan, 349.

The Emptiness of Emptiness: An Introduction to Early Indian Madhyamika (Honolulu: University of Hawai't Press, 1989): 166. (Verse 74). 


\section{Motion and Rest from a Chinese Buddhist Perspective}

argues that it is possible to have experienced something in the past of which there was no cognition or awareness at the time. A memory of this experience can then be triggered by something later on. In this case, one cannot claim that this memory is a remembrance of the actual experience since the person was not aware of the experience at the time.

Candrakīrti's idea of awareness being produced in a continuum is very much like SengChao's argument about time. Candrakīrti sees cognition as arising sequentially instead of looping back to the past or jumping ahead to the future. Memory must be independent of actual experience because the two do not ever exist in the same moment Similarly, the past and present for Seng-Chao must be distinct and separate things because they do not pas co-exist in the Sene instant must be dime. Here again, it is Seng-Chao's focus on a metaphysical co-exist in the same instant of time. Here again, it is Seng-Chao's focus on a metaphysical account of the nature of existence that sets him apart from Candrakirti's epistemological approach to explaining memory. While Candrakîrti is concerned with the way the mind processes experiences and the way people think about the past, Seng-Chao is involved in a debate about how time functions, which is a phenomenon affecting all of existence. The impermanence of all phenomena is deeply implied in his understanding of time and his 政

It is clear that Seng-Chao is using his discussion of motion and time to demonstrate the impermanence and constantly changing nature of all things. He is also connecting the idea fully uetual rest to this conception of the way things exist. Neither motion nor rest can be full them co-dependent. I would like to suggest that this is an analogy for the relationship betw the simsara and nirvana. Like notion, samsara is that which can be seen all around us all the time. Its effects are tangible and it affects all beings throughout the duration of their existence. Samsära, a cycle of rebirth and karmic retribution, is often described as flowing or circling, which again aligns it with motion. Similar to rest, nirvana is the less visible force underlying all of existence. It is always present whether or not it is recognized as being so and it is described as being a state of rest and cessation of all afflictions.

In a sense, nirvāna is just samsāra seen from a different perspective. Every being is already enlightened, but most tend to distort this and bring suffering upon themselves because they do not understand the true nature of their existence. In the same way, Seng-Chao believes that there is perpetual rest and that our minds distort reality and see everything as motion. Ultimately, samsāra and nirvāna are contained within each other and are the same thing. They are two different ways of viewing reality and each has a certain degree of truth on its own. However, each needs to be understood in relation to the other in order to fully understand the nature of the relationship and the way they function together in reality. Returning to Śāntaraksita's account of the swinging firebrand, it appears that the only thing actually being perceived is the rest (or nirvāna), and that it is the mind that creates the image of a circle and the impression that there is continuous motion (or samsāra). Upon examination, however, it is clear that there is nothing outside the multiple instances of rest. Therefore motion, while appearing to capture the nature of the perceived phenomena, is revealed as an imposition of the mind onto the perception of rest.

In the same way, samsāra is a distortion of what is actually being experienced, which is nirvāna. Because the two are closely linked, it is necessary to discover the nature of samsāra before one can fully understand nirvāna, and likewise it is impossible to fully grasp the nature of nirvāna without having knowledge about samsāra. Seng-Chao's conclusion that
Caroline Sluyter

motion and rest exist simultaneously together, and must be understood in conjunction, is therefore very similar to the relationship between the concepts of samsāra and nirvāna. Seng-Chao's discussion of motion, rest and the role that time plays in the conception of both of these, takes Buddhist ideas (as seen in the overlaps with Nāgārjuna, Śāntaraksita and Candrakīrti) and brings a new slant to them. Seng-Chao, being located in a Chinese tradition, is very much influenced by the Taoist culture in which he is immersed, and these influences can be seen in his work. Taoism is a tradition that stresses the interrelatedness, co-dependence and ultimate sameness of what appear to be opposites. "Partial means whole, crooked means straight, hollow means full, worn-out means new... thus the sage holds onto the one."14 Seng-Chao has adopted a very similar argument in relating rest and motion the one." ${ }^{\prime 14}$ Seng-Chao has adopted a very similar argument in relating rest and motion with each other, and finding each within the other. Taoism is not concerned with refuting
inherent existence, unlike Indian and Tibetan Buddhists. While Nāgāriuna's account of inherent existence, unlike Indian and Tibetan Buddhists. While Nāgārjuna's account of motion and rest accomplishes many of the same goals as Seng-Chao's treatise (the only major difference being Nāgārjuna's additional claims about emptiness), many Indian and Tibetan philosophers fail to make claims this deep. In sticking to a purely epistemological account, many of them are only able to explain the mind and its relationship to perceived external objects which it recognizes as moving.

By using a metaphysical approach, Seng-Chao is able to make deeper claims about impermanence and the nature of time because he has actual objects and phenomsabut which to work It is hard to assert the permanence or imper had inherent existence in the first place. In addition, Seng-Chao is able to explore thever as complex as the rationship between samsāra and nirvāna simply by explaining the way as complex as the relationship between samsara and nirvana simply by explaining the way existence actu the time.

It is Seng-Chao's ability to clarify important Buddhist ideas while coming from a different perspective that makes his philosophy augmentative to the Buddhist tradition. His more Taoist lens allows him to make connections that scholars immersed within the Indian and Tibetan traditions failed to see. By abandoning something as central to Mādhyamika Buddhism ${ }^{15}$ as the lack of inherent existence and the ultimate emptiness of everything, some might claim that Seng-Chao's philosophy is a gross distortion of Buddhism. Instead, I would like to suggest that he is reframing Buddhist ideas in a way that makes other very central themes (such as impermanence) crystal clear to a degree that Mādhyamika was not able to accomplish.

14. Lao-Tzu, Taoteching, Trans. Red Pine (San Francisco: Mercury House, 1996): 44 (Verse 22.
15. The Mādhyamik arisen and empty of inherent existence. Even the concept of emptiness itself is empty of true essence. 